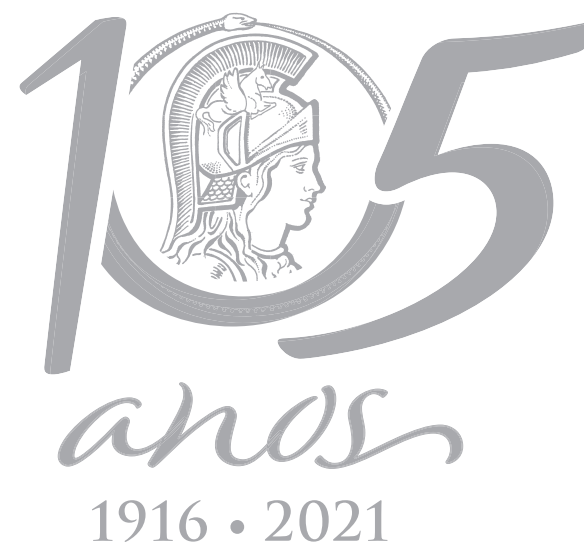

\title{
ECOSYSTEMS
}

\section{Effects of the habitat on anuran blood parasites in the Eastern Brazilian Amazon}

\author{
SÍLVIA R.C. PINHO, SÉRGIO RODRÍGUEZ-MÁLAGA, RODRIGO LOZANO-OSORIO, \\ FABRÍCIO S. CORREA, IAGO B. SILVA \& MARIA C. SANTOS-COSTA
}

\begin{abstract}
Biological interactions play an important role in regulating and maintaining natural populations. Like most interactions, parasitism may be influenced by environmental conditions. Therefore, changes caused by human activity may drastically affect the equilibrium of the assemblages of parasitized organisms (hosts). Herein, we described the composition of hemoparasites of anurans from two distinct environments: forest and oil palm plantations. We identified the most frequent groups of blood parasites, and whether infections differ between habitats (forest and plantation) and between microhabitats (arboreal or terrestrial). We collected 128 anurans, of which 46 (36\%) were parasitized by hemoparasites. The genus Trypanosoma spp. was found in $30 \%(n=37 / 128)$ of the infected anurans in both habitats, recorded mostly in terrestrial anurans in oil palm plantations. Apicomplexa hemoprotozoans were also found in $13 \%(n=17 / 128)$ of the anurans, which mainly were terrestrial species collected in oil palm plantations. There was no difference in parasitism between the two assemblies and between the studied microhabitats. This is the first study that has analyzed the ecological relationship between anurans as hosts and their blood parasites, in a region under intense anthropic pressure, in the Brazilian Amazon.
\end{abstract}

Key words: Amphibians, hemoparasites, Neotropics, oil palm plantation, parasitism.

\section{INTRODUCTION}

Biological interactions play a key role in the dynamics of natural populations. Like most interactions, parasitism can be influenced by environmental conditions (Ferreira 1973, Von Zuben 1997), which affects the development of both infection and disease (Ferreira et al. 2012). A wide variety of pathogens may cause parasitic infections, such as bacterias, fungi, helminths, and protozoans (Blaustein \& Kiesecker 2002, Luz \& Faccini 2013), with direct transmission between the hosts or through biological vectors (Telford 2009).

Environmental changes on habitats may increase parasitism (Hudson et al. 2006, Froeschke et al. 2013, Cable et al. 2017), with adverse effects on the hosts. Such effects can include consequences on the ability to prey and reproduce, and therefore, obtain resources to survive (Von Zuben 1997, Moretti et al. 2017). For this reason, parasites play an important role in natural ecosystems (Hudson etal. 2006), affecting the life of their hosts at different levels, from the individual to the population, and therefore influencing natural selection (Marcogliese et al. 2009, Thompson et al. 2010, Goater et al. 2013).

The Anura is one of the most diverse group of vertebrates in the world, including 7400 species described to date (Frost 2021). The Neotropics encompass the highest diversity (Duellman 1988, 1999, Buckley \& Jetz 2007), and in Brazil, about 1144 species were described (SBH 2021), of which 329 occur in the Amazon 
region (Censo-Museu-Goeldi 2019). Anurans are considered indicators of environmental quality due to their behavioral and physiological demands, as their dependence on water bodies and humid sites, especially during reproductive periods (Hyne et al. 2009). Besides, many environmental and anthropogenic pressures (e.g., climate change, diseases and deforestation) have caused population decline among many species (Eterovick et al. 2005). In an extreme scenario, the diseases can potentially give rise to local extinction (Silvano \& Segalla 2005). For example, chytridiomycosis is caused by the fungus Batrachochytrium dendrobatidis $(\mathrm{Bd})$, and has led to the extinction of amphibian populations in many tropical areas (ValenciaAguilar et al. 2015). The spread of this disease has been associated with changes in land use and deforestation, increasing the vulnerability of the amphibians to the pathogens (Marcogliese et al. 2009).

As the anurans inhabit various terrestrial and aquatic microhabitats, they are more susceptible to hematophagous vectors and, consequently, become infected by blood parasites (Bardsley \& Harmsen 1973, Barta \& Desser 1984). A wide variety of blood protozoans infect anurans (Desser \& Yekutiel 1986, Leal et al. 2009, Netherlands et al. 2015, Ferreira et al. 2020) and are exclusively vector-transmitted (e.g., dipterans, ticks, leeches, and others). Protozoans from the phylum Apicomplexa are the most common blood parasites of anurans, especially those of the haemogregarine group (Levine et al. 1980). Flagellates of the genus Trypanosoma (Phylum Euglenozoa) are other parasites usually found in anurans, in single or mixed infections (Honigberg 1963, Woo \& Bogart 1984, Leal et al. 2009), transmitted by mosquitoes, phlebotomies, tsetse flies, triatomines, and fleas (Simpson et al. 2006). In addition, Trypanosomatidae may be found infecting plants, a wide variety of invertebrates, and vertebrates worldwide (Vickerman 1976, Moreira et al. 2004).

Oil palm monoculture has been one of the booming activities in tropical regions (Bengtsson et al. 2000, Koh \& Wilcove 2008). The conversion of forests into oil palm monocultures has been one of the threats to biodiversity in the Amazon (Faruk et al. 2013, Cunha et al. 2015, Vijay et al. 2016, Mendes-Oliveira et al. 2017). These drastic changes in land use have affected frogs in a number of ways, including their relationship with their parasites. In this study, we evaluated the differences between the parasites and the prevalence of blood parasites in the frog communities of different habitats, including oil palm plantations, forest areas, comparing arboreal and terrestrial environments.

\section{MATERIALS AND METHODS}

\section{Study area}

The study was carried out in various forest fragments and areas of oil palm plantations (Elaeis guineensis) within the property of AGROPALMA Company (0213'00"S to 02ㄴ3'00"S and 48.54'00"W to 48.28'00"W), in the municipality of Tailândia, State of Pará, Brazil (Figure 1). The forest fragments are distributed amongst 64000 ha of the property and are covered mostly by dense upland rainforest (called terra-firme forest), with canopy trees up to $30 \mathrm{~m}$ in height. Small trees and lianas dominate the understory. In addition, there are permanent water bodies up to $20 \mathrm{~m}$ in width, while temporary water bodies are formed during the rainy season. The oil palm plantations cover 39000 ha of the property, and in these areas, the understory is less complex than in the forests, with lower microhabitat diversity, dominated by gramineans and herbaceous plants, and water bodies that are formed after heavy rains. The local climate is humid equatorial, 


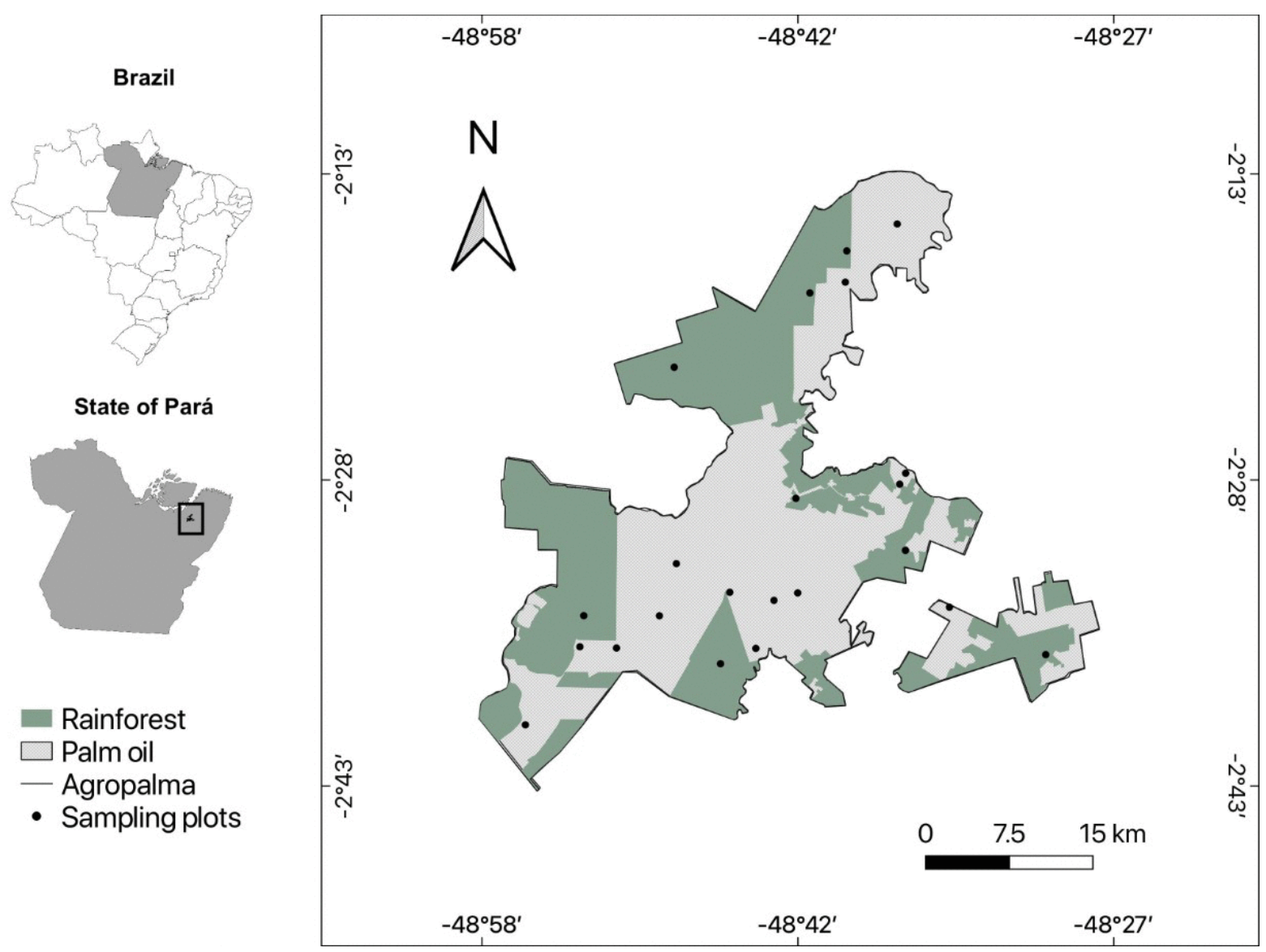

Figure 1. Map of the sampling sites within the property of AGROPALMA Company, in eastern Amazon. Black dots represent sites of forest and oil palm plantations where data was collected.

with a mean annual rainfall of $2344 \mathrm{~mm}$, and a marked rainy season between December and May (mean peak of $427 \mathrm{~mm}$ ), and a period of reduced precipitation, reaching a maximum of $54 \mathrm{~mm}$ in September (Albuquerque et al. 2010). Mean annual air temperature is approximately $260 \mathrm{C}$, and mean relative humidity of the air is approximately 85\% (Oliveira et al. 2000).

\section{Data collection}

We collected the anurans in forest habitats and oil palm plantations in two field expeditions, carried out in April 2016 and 2017, during the rainy season. We installed 12 plots of $30 \times 70$ $\mathrm{m}$ within the forest fragments and ten plots, of the same size, in oil palm plantations. All plots had a water body inside and had a minimum distance of $1 \mathrm{~km}$ between them. The forest plots were located at $1 \mathrm{~km}$ from the forest edge in order to avoid the influence of the as edge effects (Correa et al. 2015). Surveys for the presence of anurans were made through active visual searches. We moved through the plot searching for anurans on different substrates, such as litter, leaf surfaces, trunks, tree holes and water bodies. In each plot, we conducted the surveys by three experienced researchers during the day, between 2:00 pm and 5:00 pm, and at night between 7:00 pm and 10:00 pm, the inspections took place in the same plots in the two years.

The captured frogs were taken to the laboratory, and then euthanized by the application of anesthetic in the form of an 
ointment, xylocaine, in the ventral region. We followed the procedures established by the Federal Council of Veterinary Medicine (CFMV) (Ordinance 1000, 2012). In each individual, we made a ventral incision to collect blood samples directly from the heart with the aid of a syringe to make of at least two smears. All individuals were preserved in 10\% formaldehyde, for 24 hours, transferred to $70 \%$ alcohol and deposited in the temporary Herpetological Collection of the Federal University of Pará and will soon be deposited at the "Museu Paraense Emilio Goeldi", as they are being used for other studies of natural history, which are linked to a larger project, the Conservation International Brazil and AGROPALMA Company, under the license 8716-1 (process: 12420-2). For each individual, the following data were recorded: date of collection, field number, species, sampling plot, tissue sample and blood smear for parasitism analysis, substrate, microhabitat, weight, and size.

The smears were fixed in cold methanol for one minute. Subsequently, they were stained for 30 minutes, using Giemsa diluted in buffered water. To confirm the presence of hemoparasites, blood smears were analyzed using an Olympus BX41 microscope at 100x total magnification, observing 20 fields of each slide. The images were captured with a CCD Camera (AxioCam MR monochrome) coupled to a Zeiss Axiophot microscope controlled by the Axiovision 3.0 software. The characterization of hemoparasites was carried out through the morphological analysis of each parasitized sample. Molecular analysis was not possible. The parasites of the genus Trypanosoma were evaluated from the morphology analysis following the classification proposed by Diamond (1965), Desser (2001) and Zickus (2002), including five groups: Group A: Flat and leaf-shaped body (Figure 2: 1, 2); Group B: Body, in frontal view, flat, but not in the form of a leaf; laterally, it presents a wide anterior

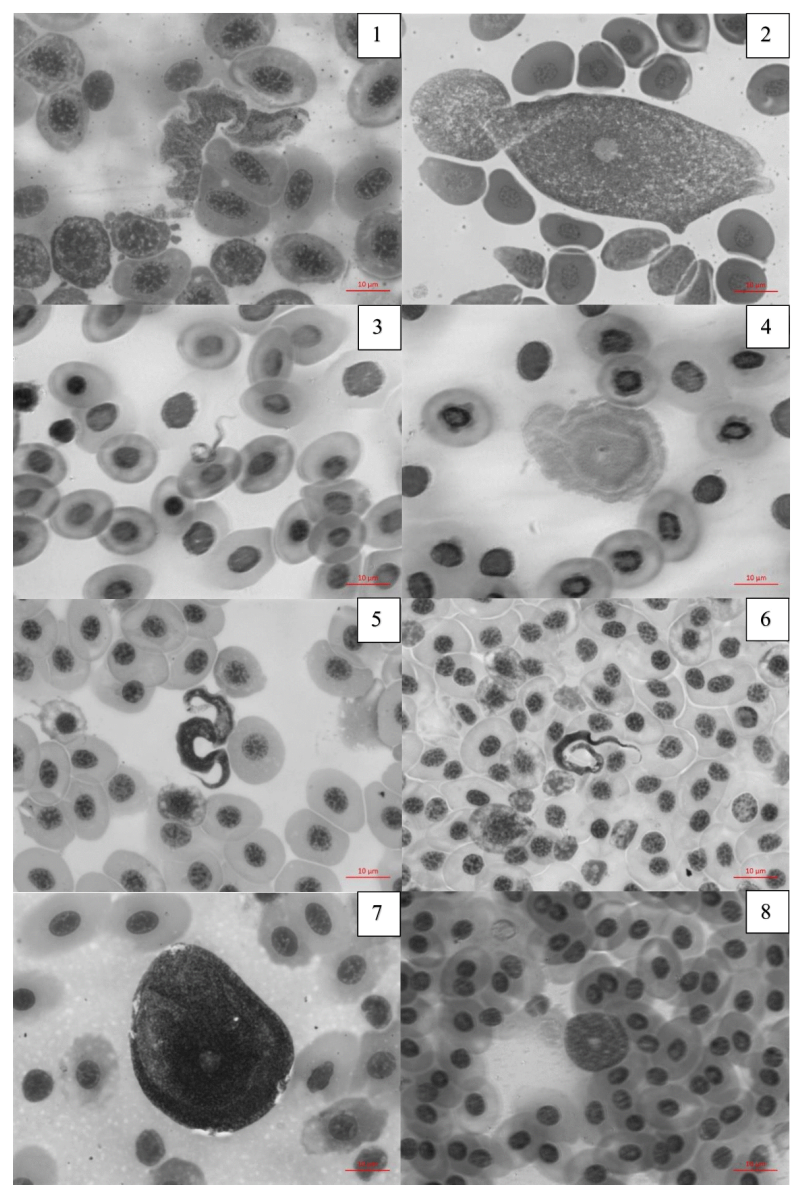

Figure 2. Characterization of Trypanosoma parasites found in anurans from forest areas and oil palm plantations in the municipality of Tailândia, Pará, Brazil. 1) Group A (Osteocephalus oophagus); 2) Group A (Scinax gr. ruber); 3) Group B (Leptodactylus fuscus); 4) Group C (Physalaemus ephippifer); 5) Group D1 (Leptodactylus macrosternum); 6) Group D2 (L. macrosternum); 7) Group F (Boana geographica); 8) Group F (L. macrosternum). Scale $=10 \mu \mathrm{m}$. Species between parentheses $=$ Anurans .

region, starting from the kinetoplast, which narrows later (Figure 2: 3); Group C: Robust body, frontally compressed and ovoid; laterally robust, elliptical, about twice as long as it is wide (Figure 2: 4); Group D: Elongated body, narrow extremities; D1: Kinetoplast closer to the nucleus than to the posterior end (Figure 2: 5); D2: Kinetoplast closer to the posterior end than to the nucleus (Figure 2: 6); Group F: Spherical body (Figure 2: 7, 8). Apicomplexa hemoprotozoans 


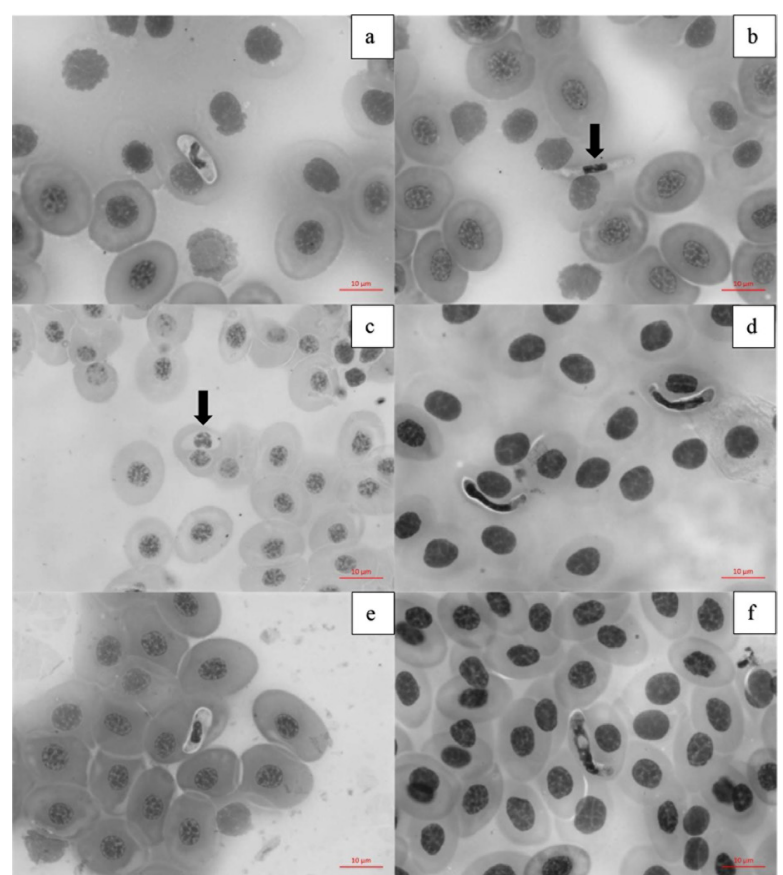

Figure 3. Hemoparasites of the phylum Apicomplexa in the peripheral blood of the anurans sampled in forest and oil palm plantations, Eastern Amazon, Brazil: a (Leptodactylus pentadactylus); b (L. pentadactylus); c (L. macrosternum); d (L. pentadactylus); e ( $L$. pentadactylus); $\mathrm{f}$ (L. pentadactylus). Scale $=10 \mu \mathrm{m}$. Species between parentheses $=$ Anurans.

were characterized with the help of specialists of the Parasitology laboratory of the Federal University of Pará and following Telford (2009).

\section{Data analysis}

We used a Mann-Whitey U test (Zar 2010) and chi-square test ( $x 2)$ with Yates' correction and significance level $P \leq 0.05$ to analyze whether there is any difference in the prevalence of infection with blood parasites (hemogregarines and trypanosomes) in anurans between forest and oil palm plantations. We used the same test to analyze whether there is any difference in the prevalence of infection with blood parasites in anurans between microhabitats (arboreal and terrestrial). The analyses were run in $\mathrm{R}$ Project software (R Development Core Team 2017).

\section{RESULTS}

We made blood smears from 128 anurans representing 27 species of five families and 13 genera, of the total species, 21 occurring in the forest, 14 from oil palm plantations, and 8 occurring in common in the two areas. We collected 65 individuals from forest fragments and 63 from oil palm plantations. Sixteen arboreal anuran species (68 individuals) and 12 terrestrial species (60 individuals). We found $36 \%$ ( $n=$ $46 / 128)$ of the individuals with hemoparasites (Table I), 28\% ( $n=18 / 65$ ) of which were found in forest fragments and $44 \%(n=28 / 63)$ in oil palm plantations. Terrestrial anurans had prevalence varying from $31 \%(n=8 / 26)$ to $62 \%$ $(n=21 / 34)$, in forest and oil palm plantation areas, respectively. For arboreal anurans the proportion of infected hosts was similar for both habitats, $24 \%(n=7 / 29)$ in oil palm plantations, and $26 \%(n=10 / 39)$ in forest sites. Regarding the anuran species, the most infected in oil palm plantations were Leptodactylus fuscus (100\%; $\mathrm{n}=4 / 4)$ and Leptodactylus macrosternum (82\%; $n=9 / 11)$, and in forest fragments were Trachycephalus typhonius (100\%; $n=2 / 2$ ) and Leptodactylus pentadactylus (71\%; $n=5 / 7)$. The host species that showed the lowest prevalence were Boana multifasciata $(10 \% ; n=1 / 10)$ in forest, and Physalaemus ephippifer (20\%; $n=$ $1 / 5)$ in oil palm plantation (Table I).

Among positive individuals from both environments, we found $80 \%(n=37 / 46)$ were infected with trypanosomes (Figure 2 ) and 37\% $(n=17 / 46)$ with apicomplexan hemoparasites (Figure 3). Mixed infections by these two parasites groups were observed at a prevalence of $6.2 \%$ (n $=8 / 128$ ). Leptodactylus pentadactylus was the only species to harbor mixed infections in the forest area, with a prevalence of $6.1 \%(n=4 / 65)$. In oil palm plantations, $6.3 \%(n=4 / 63)$ of the individuals, all terrestrial species (Leptodactylus macrosternum and Leptodactylus mystaceus), showed mixed infections. 
Table I. Anurans with hemoparasites infections in forest fragments and oil palm plantation areas within the property of AGROPALMA Company, in Tailândia, Pará, Brazil. Api = Apicomplexa hemoprotozoans; Tryp = Trypanosoma.

\begin{tabular}{|c|c|c|c|c|}
\hline Habitat type & Species & Arboreal & Terrestrial & $\begin{array}{c}\text { Hemoparasites/ } \\
\text { Anurans }\end{array}$ \\
\hline \multirow[t]{21}{*}{ Forest } & Boana cinerascens & 7 & & - \\
\hline & Boana geographica & 3 of 7 & & Tryp (3) \\
\hline & Boana multifasciata & 1 of 10 & & Tryp (1) \\
\hline & Dendropsophus leucophyllatus & 1 & & - \\
\hline & Dendropsophus minutus & 1 of 1 & & Tryp (1) \\
\hline & Leptodactylus fuscus & & 1 of 3 & Tryp (1) \\
\hline & Leptodactylus macrosternum & & 1 & - \\
\hline & Leptodactylus pentadactylus & & 5 of 7 & Api (5); Tryp (4) \\
\hline & Leptodactylus petersii & & 2 & - \\
\hline & Osteocephalus leprieurii & 1 & & - \\
\hline & Osteocephalus oophagus & 1 of 1 & & Tryp (1) \\
\hline & Phyllomedusa bicolor & 1 of 3 & & Tryp (1) \\
\hline & Physalaemus ephippifer & & 5 & - \\
\hline & Pithecopus hypochondrialis & 1 of 3 & & Tryp (1) \\
\hline & Rhaebo guttatus & & 1 & - \\
\hline & Rhinella gr. margaritifera & & 1 of 4 & Tryp (1) \\
\hline & Rhinella marina & & 2 & - \\
\hline & Rhinella mirandaribeiroi & & 1 of 1 & Tryp (1) \\
\hline & Scinax nebulosus & 2 & & - \\
\hline & Trachycephalus typhonius & 2 of 2 & & Tryp (2) \\
\hline & Vitreorana oyapiensis & 1 & & - \\
\hline Total & 21 & 10 of 39 & 8 of 26 & Api (5); Tryp (17) \\
\hline \multirow[t]{8}{*}{ Oil palm plantation } & Boana multifasciata & 3 of 6 & & Api (2); Tryp (1) \\
\hline & Leptodactylus fuscus & & 4 of 4 & Api (1); Tryp (3) \\
\hline & Leptodactylus macrosternum & & 9 of 11 & Api (4); Tryp (7) \\
\hline & Leptodactylus mystaceus & & 2 of 4 & Api (1); Tryp (2) \\
\hline & Leptodactylus paraensis & & 2 of 2 & Api (1); Tryp (1) \\
\hline & Physalaemus ephippifer & & 1 of 5 & Tryp (1) \\
\hline & Pithecopus hypochondrialis & 7 & & - \\
\hline & Rhinella marina & & 1 of 1 & Api (1) \\
\hline
\end{tabular}


Table I. Continuation.

\begin{tabular}{|c|c|c|c|c|}
\hline & Rhinella mirandaribeiroi & & 2 of 7 & Tryp (2) \\
\hline & Scinax boesemani & 1 & & - \\
\hline & Scinax gr. ruber & 2 of 8 & & Api (1); Tryp (2) \\
\hline & Scinax -signatus & 1 & & - \\
\hline & Sphaenorhynchus lacteus & 1 & & - \\
\hline & Trachycephalus typhonius & 2 of 5 & & Api (1); Tryp (1) \\
\hline Total & $\mathbf{1 4}$ & $\mathbf{7}$ of $\mathbf{2 9}$ & $\mathbf{2 1}$ of $\mathbf{3 4}$ & Api (12); Tryp (20) \\
\hline
\end{tabular}

We identified six of the seven proposed morphological groups of trypanosomes (Table II), showing a high morphological diversity of trypomastigote forms. In addition, only in forest, we found 17 out of 65 individuals with trypanosomes in their peripheral blood, most of them arboreal (Dendropsophus minutus, Boana geographica, Boana multifasciata, Osteocephalus oophagus, Phyllomedusa bicolor, Pithecopus hypochondrialis and Trachycephalus typhonius)(Table II). In oil palm plantations, 17 out of 20 individuals infected by trypanosomes were terrestrial (Leptodactylus fuscus, Leptodactylus macrosternum, Leptodactylus mystaceus, Leptodactylus paraensis, Physalaemus ephippifer and Rhinella mirandaribeiroi) (Table II).

The second group of parasites observed was apicomplexan hemoprotozoans (Figure 3), occurring in $13 \%(n=17 / 128)$ of the sampled hosts. Among these infected anurans, 19\% ( $n=$ $12 / 63)$ were found in the oil palm plantation area and $7.6 \%(n=5 / 65)$ in the forest area, mainly in terrestrial anurans $82 \%(n=14 / 17)$ from six species (Table II), while in arboreal anurans they were discovered in only three individuals all within the oil palm plantation.

We analyzed whether there is any difference in parasitism between individuals in forest areas $28 \%(n=18 / 65)$ and oil palm plantations 44\% ( $n$ $=28 / 63)$ and found no difference $\left(X^{2}=3.206, P=\right.$ 0.073 ). We made the same comparison using only individuals infected with trypanosomes in forest areas $26 \%(n=17 / 65)$ and oil palm plantations $33 \%(n=21 / 63)$ and once again observed no difference $\left(X^{2}=0.483, P=0.486\right)$.

Considering the forest plots, three of them were positioned close to the edge. To check if these plots could be influencing the results, so a test was carried out, which showed no differences $\left(X^{2}=0.113, P=0.737\right)$ between the infected anurans collected inside the forest ( $n=$ 13/54) and the infected anurans collected close to the forest edge $(n=4 / 11)$. Also, there was no difference when randomly selecting the three plots within the forest $(n=5 / 19)$ and comparing them with the three plots close to the edge $\left(X^{2}=\right.$ 0.312, $P=0.575$ ).

The analyses of the Mann-Whitney $U$ test showed no differences between the prevalence of parasitism in anurans found in the forest and oil palm plantations $(P=0.329)$. We also tested for differences in the prevalence of parasitism according to the habit of anurans (arboreal and terrestrial) in each habitat type. We found that in oil palm plantations $62 \%(n=21 / 34)$ there were more parasitized terrestrial anurans than in forest areas 31\% $(n=8 / 26)\left(X^{2}=4.494, P=\right.$ $0.034)$, whereas the prevalence of parasitism in arboreal anurans did not differ between the forest $26 \%(n=10 / 39)$ and oil palm plantations $28 \%(n=8 / 29)\left(X^{2}=0, P=1.00\right)$.

In the forest and oil palm plantations we also found differences in the distribution of 
hemoparasites, with more individuals infested with trypanosomes 26\% ( $n=17 / 65)$ than apicomplexa hemoprotozoans 7\% $(n=5 / 65)$ in the forest $\left(X^{2}=6.620, P=0.010\right)$, while there was no difference between infections with trypanosomes 33\% $(n=21 / 63)$ and apicomplexa hemoprotozoans $17 \%(n=11 / 63)$ in oil palm plantations $\left(X^{2}=3.393, P=0.065\right)$.

\section{DISCUSSION}

In this study, the prevalence was relatively high and contrasts with other results observed in anurans in modified areas. In Brazil, Leal et al. (2009) found $20 \%$ of the 40 anurans collected in São Paulo (Atlantic Forest) and Mato Grosso do Sul (Pantanal) were infected with hemoparasites. Similarly, in northern South Africa, Netherlands et al. (2015) observed that only $20 \%$ of the 436 anurans were infected in three different landscapes: reserve, rural activity and sugar cane agriculture. These differences can be explained by the different levels of human disturbance that occur in these locations. However, it is necessary to emphasize that the Amazon region, where our study was conducted, is recognized for harboring a great diversity of host fauna and their hemoparasites (Lainson et al. 1992, Picelli et al. 2020), although this last one is little known in anurans.

Regarding blood parasites in anurans, trypanosomes were the most prevalent in both habitats. These protozoans are commonly found in anurans blood worldwide (Bardsley \& Harmsen 1973), with a large number of hematophagous vectors (Simpson et al. 2006). We observed that 16 out of 17 species in both habitats (forest and oil palm plantations) were infected by trypanosomes, except Rhinella marina. However, Attias et al. (2016) observed that this species is susceptible to trypanosome infections too. Recently, Úngari et al. (2021) carried out a study in the state of Mato Grosso and captured three host species in common to our survey, L. petersii, R. mirandaribeiroi and T. typhonius, but without finding hemoparasites in the last two anuran species as we did here.

Besides the morphological diversity of trypanosomes infecting anurans, one single Trypanosoma species may have a high degree of polymorphism when it infects different anuran species (Scorza \& Dagert 1958, Spodareva et al. 2018). These morphological differences may be caused by the differential expression of the same genome or by infection from several lineages of the same parasite (Ferreira et al. 2007). Despite the lack of molecular analysis, we found a high morphological diversity, based on Diamond (1965), together with other studies (Desser 2001, Zickus 2002), which allowed us to identify six morphological groups of trypanosomes. Our results show that most infections of trypanosomes were caused by morphotypes $A$ and $D$, indicating a wide distribution of those flagellates in both habitats (forest and oil palm plantations). In another study, Zickus (2002) identified four morphotypes that were attributed to Trypanosoma rotatorium. These morphotypes were found in the peripheral blood of the anurans from Lithuania in the same prevalence in both habitat types of the study (Zickus 2002).

Similarly, infections of apicomplexan hemoprotozoans occurred more often in oil palm plantations, where 12 individuals $43 \%$ (n $=12 / 28$ ) were infected. In forest areas we found only five terrestrial anurans $28 \%(n=5 / 18)$, all of which L. pentadactylus were infected with apicomplexa hemoprotozoans. However, they appeared less frequently in the total of analyzed anurans. Our findings differ, for example, from those of other studies conducted in Africa, where hemogregarines are more frequent in the 
Table II. Parasites of the genus Trypanosoma in anurans from forest areas and oil palm plantations in the municipality of Tailândia, Pará, Brazil.

\begin{tabular}{|c|c|c|}
\hline Individuals/Habitat & Habit & Trypanosoma groups \\
\hline Forest & \multirow{2}{*}{ Arboreal } & \multirow{2}{*}{ D2 } \\
\hline Dendropsophus minutus & & \\
\hline Boana multifasciata & Arboreal & A \\
\hline Boana geographica & Arboreal & $A ; F$ \\
\hline Boana geographica & Arboreal & A; D1 \\
\hline Boana geographica & Arboreal & D1 \\
\hline Leptodactylus fuscus & Terrestrial & D2 \\
\hline Leptodactylus pentadactylus & Terrestrial & D1 \\
\hline Leptodactylus pentadactylus & Terrestrial & $\mathrm{A} ; \mathrm{D} 1 ; \mathrm{D} 2 ; \mathrm{F}$ \\
\hline Leptodactylus pentadactylus & Terrestrial & D1 \\
\hline Leptodactylus pentadactylus & Terrestrial & D1 \\
\hline Osteocephalus oophagus & Arboreal & A \\
\hline Phyllomedusa bicolor & Arboreal & $A ; C$ \\
\hline Pithecopus hypochondrialis & Arboreal & A \\
\hline Rhinella mirandaribeiroi & Terrestrial & $\mathrm{F}$ \\
\hline Rhinella gr. margaritifera & Terrestrial & $\mathrm{F}$ \\
\hline Trachycephalus typhonius & Arboreal & A \\
\hline Trachycephalus typhonius & Arboreal & A \\
\hline Oil palm plantations & \multirow{2}{*}{ Arboreal } & \multirow{2}{*}{ D2 } \\
\hline Boana multifasciata & & \\
\hline Leptodactylus fuscus & Terrestrial & B; D1; D2 \\
\hline Leptodactylus fuscus & Terrestrial & A; D1; D2 \\
\hline Leptodactylus fuscus & Terrestrial & $A ; F$ \\
\hline Leptodactylus macrosternum & Terrestrial & A; D1; D2 \\
\hline Leptodactylus macrosternum & Terrestrial & A \\
\hline Leptodactylus macrosternum & Terrestrial & D2 \\
\hline Leptodactylus macrosternum & Terrestrial & $\mathrm{D} 1 ; \mathrm{F}$ \\
\hline Leptodactylus macrosternum & Terrestrial & $\mathrm{F}$ \\
\hline Leptodactylus macrosternum & Terrestrial & A \\
\hline Leptodactylus macrosternum & Terrestrial & D1; D2 \\
\hline Leptodactylus macrosternum & Terrestrial & A \\
\hline Leptodactylus mystaceus & Terrestrial & A \\
\hline Leptodactylus paraensis & Terrestrial & $\mathrm{F}$ \\
\hline Physalaemus ephippifer & Terrestrial & $\mathrm{C}$ \\
\hline Rhinella mirandaribeiroi & Terrestrial & D2 \\
\hline Rhinella mirandaribeiroi & Terrestrial & D2 \\
\hline
\end{tabular}


Table II. Continuation

\begin{tabular}{|c|c|c|}
\hline Scinax gr. ruber & Arboreal & A; D1 \\
\hline Scinax gr. ruber & Arboreal & A; D1 \\
\hline Trachycephalus typhonius & Arboreal & D2 \\
\hline Total $=\mathbf{3 7}$ & & \\
\hline
\end{tabular}

blood of anurans than other protozoans (Readel \& Goldberg 2010, Netherlands et al. 2015).

Comparing the number of infections between forest and oil palm plantations, we observed that, in most cases, infections were by Trypanosoma and more frequent in oil palm plantations. Anurans in disturbed areas are more susceptible to interactions with hematophagous vectors of these parasites (Borkent 2008, Bernal \& Pinto 2016). Dipterans of the genus Corethrella are known to be vectors of trypanosomes (Johnson et al. 1993, Ferguson \& Smith 2012, Aihara et al. 2016) and benefit from changes in habitat, which in turn increases the chances of interactions with anurans and the transmission of blood parasites (Ambrozio-Assis et al. 2018).

In the human population, a similar effect can be observed through the transmission of pathogens, where changes in climatic factors associated with a high level of disturbances may affect the transmission of vector-transmitted pathogens (Cable et al. 2017). As a consequence, both transmission and occurrence of parasites may increase or decrease due to human activities. In other words, although parasitism is a natural interaction, its effects differ, and this interaction may cause diseases with habitat changes (Bower et al. 2019). Therefore, the composition and diversity of the parasite community may vary, and indicating environmental stress (Marcogliese 2005). Parasites of amphibians are indicators of ecosystem health and animal biodiversity, acting as indicators for conservation (King et al. 2010).

Homogeneous and less complex environments, such as monocultures, usually have a significant loss of biodiversity. Concerning oil palm plantations, this environment supports a much smaller diversity of anurans than preserved forests (Correa et al. 2015). In addition to the decrease in the diversity of anurans, it was observed that animals infected with blood parasites were mainly terrestrial species, indicating that anurans are more susceptible to stress due to habitat conversion (McMahon et al. 2017) and pathogen vectors (Ferguson \& Smith 2012). Therefore, preserved forests are essential in maintaining a great diversity of microhabitats and the fauna that exploits these microhabitats.

In our study, we carried out the detection of parasites by microscopic observation. In wild animals, the incidence of parasites in a population can be calculated using three techniques, which are not mutually exclusive: blood culture, molecular diagnosis, or microscopic observation of peripheral blood samples. The isolation of these parasites by means of culture in axenic media is limited to studies of extracellular parasites, preventing the performance of the procedure with intraerythrocyte parasites (Ferreira et al. 2007, Attias et al. 2016). On the other hand, microscopic observation allows the detection of various parasites belonging to different taxa, but their sensitivity is compromised in infections with a low parasitic load (Leal et al. 2009, Rajabi et al. 2017, Picelli et al. 2020). Finally, the use of molecular tools (PCR) allows both the detection of parasites with high sensitivity and the sequencing for phylogeny studies (Ferreira et al. 2020). However, the intrinsic specificity 
of molecular techniques can compromise the detection of parasites with high diversity. In addition, studies that combine morphology and molecular analysis are considered more complete (de Oliveira et al. 2018, Isaak-Delgado et al. 2020).

The morphological observation allowed us to conclude that hemoparasites are highly diverse in both types of habitat. In this scenario, new studies are extremely important and recommended in our region, using principally molecular techniques, as well and also the characterization of possible vectors, which may assist researchers to recognize and understand the diversity and understand the degree of alterations in the transmission of pathogens of anurans in altered environments.

\section{Acknowledgments}

We thank to Coordenação de Aperfeiçoamento de Pessoal de Nivel Superior (CAPES) for scholarship grants to SRCP; Zoology Post-graduation program of UFPA/MPEG; Partnerships for International Research and Education (PIRE-USA); International Conservation Brazil ( $\mathrm{Cl})$ and AGROPALMA Company. We are all grateful to IBAMA for permission to collect anurans under the license 8716-1 (process: 12420-2). We also thank Crescer - Coworking de Psicologia for allowing us to use their space to produce part of this manuscript and Jesse Daniel Carlton for English review.

\section{REFERENCES}

AIHARA I, DE SILVA P \& BERNAL XE. 2016. Acoustic Preference of Frog-Biting Midges (Corethrella spp) Attacking Túngara Frogs in their Natural habitat. Ethology 122: 105-113.

ALBUQUERQUE MF, SOUZA EB, OLIVEIRA MCF \& SOUZA-JR JA. 2010. Precipitação nas mesorregiões do Estado do Pará: Climatologia, variabilidade e tendências nas últimas décadas (1978-2008). Rev Bras Climatol 6: 151-168.

AMBROZIO-ASSIS A, CORTÊS LOPES B, AMARAL AP, PINHO LC, PEETERS ET \& NECKEL-OLIVEIRA S. 2018. Preferences for anuran calls in hematophagous corethrellids (Diptera: Corethrellidae) from Southern Brazil. Austral Entomol 58: 622-628.
ATTIAS M, SATO LH, FERREIRA RC, TAKATA CS, CAMPANER M, CAMARGO EP, TEIXEIRA MMG \& SOUZA W. 2016. Developmental and Ultrastructural Characterization and Phylogenetic Analysis of Trypanosoma herthameyeri n. sp. of Brazilian Leptodactilydae Frogs. J Eukaryot Microbiol 63: 610-622.

BARDSLEY JE \& HARMSEN R. 1973. The trypanosomes of anura. In Advances in Parasitology. Academic Press 11: 1-73.

BARTA JR \& DESSER SS. 1984. Blood parasites of amphibians from Algonquin Park, Ontario. J Wild Diseases 20: 180-189.

BENGTSSON J, NILSSON SG, FRANC A \& MENOZZI P. 2000. Biodiversity, disturbances, ecosystem function and management of European forests. Forest Ecol Manag 132: 39-50.

BERNAL XE \& PINTO CM. 2016. Sexual differences in prevalence of a new species of trypanosome infecting túngara frogs. Int J Parasitol Parasites Wild 5: 40-47.

BLAUSTEIN AR \& KIESECKER JM. 2002. Complexity in conservation: lessons from the global decline of amphibian populations. Ecol Lett 5: 597-608.

BORKENT A. 2008. The frog-biting midges of the world (Corethrellidae: Diptera). Purrujas de las ranas del Mundo (Corethrellidae: Diptera). Zootaxa 1804: 1-456.

BOWER DS, BRANNELLY LA, MCDONALD CA, WEBB RJ, GREENSPAN SE, VICKERS M, GARDNER MG \& GREENLEES MJ. 2019. A review of the role of parasites in the ecology of reptiles and amphibians. Austral Ecol 44: 433-448.

BUCKLEY LB \& JETZ W. 2007. Environmental and historical constraints on global patterns of amphibian richness. $P$ Roy Soc Lond B Bio 274: 1167-1173.

CABLE J, BARBER I, BOAG B, ELLISON AR, MORGAN ER, MURRAYK, PASCOE EL, SAIT SM, WILSON AJ \& BOOTH M. 2017. Global change, parasite transmission and disease control: lessons from ecology. Phil Trans R Soc B 372(1719): 20160088.

CENSO-MUSEU-GOELDI. 2019. Programa Biodiversidade da Amazônia. http://censo.museu-goeldi.br:8080/ museugoeldi-web-1.2.0/paginas/index.xhtml, accessed on 20 March 2021.

CORREA FS, JUEN L, RODRIGUES LC, SILVA-FILHO HF \& SANTOSCOSTA MC. 2015. Effects of oil palm plantations on anuran diversity in the eastern Amazon. Anim Biol 65: 321-335.

CUNHA EJ, DE ASSIS MONTAG LF \& JUEN L. 2015. Oil palm crops effects on environmental integrity of Amazonian streams and Heteropteran (Hemiptera) species diversity. Ecol Indic 52: 422-429. 
DE OLIVEIRA JP, ANDRÉ MR, JÚNIOR JR FA, LUSTOSA APG \& WERTHER K. 2018. Molecular detection of hemogregarines and haemosporidians in Brazilian free-living testudines. Int J Parasitol Parasites Wild 1: 75-84.

DESSER SS. 2001. The blood parasites of anurans from Costa Rica with reflections on the taxonomy of their trypanosomes. J Parasitol 87: 152-160.

DESSER SS \& YEKUTIEL D. 1986. Blood parasites of amphibians and reptiles in Israel. Isr J Zool 34: 77-90.

DIAMOND LS. 1965. A study of the morphology, biology and taxonomy of the trypanosomes of Anura. Wildl Dis 44: 1-85.

DUELLMAN WE. 1988. Patterns of species diversity in anuran amphibians in the American tropics. Ann Mo Bot Gard, p. 79-104.

DUELLMAN WE. 1999. Global distribution of amphibians: patterns, conservation, and future challenges (p. 1-30). Johns Hopkins University Press, Baltimore, MD, USA.

ETEROVICK PC, DE QUEIROZ CARNAVAL ACO, BORGES-NOJOSA DM, SILVANO DL, SEGALLA MV \& SAZIMA I. 2005. Amphibian Declines in Brazil: An Overview 1. Biotropica 37: 166-179.

FARUK A, BELABUT D, AHMAD N, KNELL RJ \& GARNER TW. 2013. Effects of oil-palm plantations on diversity of tropical anurans. Conserv Biol 27: 615-624.

FERGUSON LV \& SMITH TG. 2012. Reciprocal trophic interactions and transmission of blood parasites between mosquitoes and frogs. Insects 3: 410-423.

FERREIRA DDAR, PERLES L, MACHADO RZ, PRADO CP \& ANDRÉ MR. 2020. Molecular detection of Apicomplexan hemoparasites in anurans from Brazil. Parasitol Res 10: 3469-3479.

FERREIRA LF. 1973. O fenômeno parasitismo. Rev Soc Bras Med Trop 7: 261-277.

FERREIRA LF, CHIEFFI PP \& ARAUJO A. 2012. Parasitismo não é doença parasitária. Norte Ciência 3: 200-221.

FERREIRA RC, CAMPANER M, VIOLA LB, TAKATA CSA, TAKEDA GF \& TEIXEIRA MMG. 2007. Morphological and molecular diversity and phylogenetic relationships among anuran trypanosomes from the Amazonia, Atlantic Forest and Pantanal biomes in Brazil. Parasitology 134: 1623-1638.

FROESCHKE G, VAN DER MESCHT L, MCGEOCH M \& MATTHEE S. 2013. Life history strategy influences parasite responses to habitat fragmentation. Int J Parasitol 43: 1109-1118.

FROST DR. 2021. Amphibian Species of the World: An Online Reference. Version 6.0. American Museum of Natural History, New York, USA. Electronic Database available at: http://research.amnh.org/vz/herpetology/ amphibia/index.php, accessed on 8 June 2021.

GOATER TM, GOATER CP \& ESCH GW. 2013. Parasitism: the diversity and ecology of animal parasites. Cambridge University Press, United Kingdom.

HONIGBERG BM. 1963. Evolutionary and systematic relationships in the flagellate order Trichomonadida Kirby. J Eukaryot Microbiol 10: 20-63.

HUDSON PJ, DOBSON AP \& LAFFERTY KD. 2006. Is a healthy ecosystem one that is rich in parasites? Trends Ecol Evol 21: 381-385.

HYNE RV, WILSON S \& BYRNE M. 2009. Frogs as bioindicators of chemical usage and farm practices in an irrigated agricultural area. Final Report to Land \& Water Australia, $33 \mathrm{p}$.

ISAAK-DELGADO AB, LÓPEZ-DÍAZ O, ROMERO-CALLEJAS E, MARTÍNEZ-HERNÁNDEZ F, MUÑOZ-GARCÍA CI, VILLALOBOS G \& RENDÓN-FRANCO E. 2020. Morphological and molecular characteristics of hemoparasites in vaillant's frogs (Lithobates vaillanti). Parasitol Res 6: 1891-1901.

JOHNSON RN, YOUNG DG \& BUTLER JF. 1993. Trypanosome transmission by Corethrella wirthi (Diptera: Chaoboridae) to the green treefrog, Hyla cinerea (Anura: Hylidae). J Med Entomol 30: 918-921.

KING KC, MCLAUGHLIN JD, BOILY M \& MARCOGLIESE DJ. 2010. Effects of agricultural landscape and pesticides on parasitism in native bullfrogs. Biol Conserv 143: 302-310.

KOH LP \& WILCOVE DS. 2008. Is oil palm agriculture really destroying tropical biodiversity?. Conserv Lett 1: 60-64.

LAINSON R. 1992. A protozoologist in Amazonia: Neglected parasites, with particular reference to member of Coccidia (Protozoa: Apicomplexa). Ciên Cult 44: 81-93.

LEAL DD, O'DWYER LH, RIBEIRO VC, SILVA RJ, FERREIRA VL \& RODRIGUES RB. 2009. Hemoparasites of the genus Trypanosoma (Kinetoplastida: Trypanosomatidae) and hemogregarines in anurans of the São Paulo and Mato Grosso do Sul States-Brazil. An Acad Bras Cienc 81: 199-206.

LEVINE ND ET AL. 1980. A newly-revised classification of the Protozoa. J Protozool 27: 37-58.

LUZ HR \& FACCINI JLH. 2013. Parasitismo por carrapatos em anuros no Brasil. Revisão Vet Zootec 20: 100-111.

MARCOGLIESE DJ. 2005. Parasites of the superorganism: are they indicators of ecosystem health? Int J Parasitol 35: 705-716. 
MARCOGLIESE DJ, KING KC, SALO HM, FOURNIER M, BROUSSEAU P, SPEAR P, CHAMPOUX L, MCLAUGHLIN JD \& BOILY M. 2009. Combined effects of agricultural activity and parasites on biomarkers in the bullfrog, Rana catasbeiana. Aquat Toxicol 91: 126-134.

MCMAHON TA, ROHR JR \& BERNAL XE. 2017. Light and noise pollution interact to disrupt interspecific interactions. Ecology 98: 1290-1299.

MENDES-OLIVEIRA AC, PERES CA, MAUÉS PCRDA, OLIVEIRA GL, MINEIRO IG, DE MARIA SLS \& LIMA RC. 2017. Oil palm monoculture induces drastic erosion of an Amazonian forest mammal fauna. PLOS ONE 12(11): e0187650.

MOREIRA D, LÓPEZ-GARCIA P \& VICKERMAN K. 2004. Na updated view of kinetoplastid phylogeny using environmental sequences and a closer outgroup: proposal for a new classification of the class Kinetoplastea. Int J Syst Evol Microbiol 54: 1861-1875.

MORETTI EH, TITON JRB, MADELAIRE CB, DE ARRUDA R, ALVAREZ T \& GOMES FR. 2017. Behavioral, physiological and morphological correlates of parasite intensity in the wild Cururu toad (Rhinella icterica). Int J Parasitol Parasites Wild 6: 146-154.

NETHERLANDS EC, COOK CA, KRUGER DJ, DU PREEZ LH \& SMIT NJ. 2015. Biodiversity of frog haemoparasites from subtropical northern KwaZulu-Natal, South Africa. Int J Parasitol Parasites Wild 4: 135-141.

OLIVEIRA LL, FONTINHAS RL, LIMA AMM \& LIMA RJS. 2000. Mapas dos parâmetros climatológicos do Estado do Pará: Umidade, temperatura e insolação, médias anuais. XIII Congresso Brasileiro de Meteorologia. 29/08 a 03/09/2000. Fortaleza - Ceará. Núcleo de Hidrometeorologia - SECTAM.

PICELLI AM, RAMIRES AC, MASSELI GS, PESSOA FA, VIANA LA \& KAEFER IL. 2020. Under the light: high prevalence of haemoparasites in lizards (Reptilia: Squamata) from Central Amazonia revealed by microscopy. An Acad Bras Cienc 92: e20200428.

RAJABI F, JAVANBAKHT H \& SAJJADI SS. 2017. A preliminary study of haemoparasites in marsh frogs, Pelophylax ridibundus (Ranidae) from Iran. J Entomol Zool Stud 5: 1314-1317.

READEL AM \& GOLDBERG TL. 2010. Blood parasites of frogs from an equatorial African montane forest in western Uganda. J Parasitol 96: 448-450.

R DEVELOPMENT CORE TEAM. 2017. R: A Language and Environment for Statistical 449 Computing. R Foudation for Statistical Computing, Viena, Austria. Accessible at: http://www.r-project.org.
SCORZA JV \& DAGERT CM. 1958. Sobre la sinonímia del Trypanosoma rotatorium Mayer, 1843, em batracios de Venezuela. B Venezoel Lab Clin 3: 29-36.

SILVANO DL \& SEGALLA MV. 2005. Conservation of Brazilian amphibians. Conserv Biol 19: 653-658.

SIMPSON AG, STEVENS JR \& LUKEŠ J. 2006. The evolution and diversity of kinetoplastid flagellates. Trends Parasitol 4: 168-174.

SBH. 2021. Lista de espécies de anfíbios do Brasil. Sociedade Brasileira de Herpetologia (SBH). Available at: http://public.sbherpetologia.org.br/assets/revista/ HB10.1_2021_01 20210511103022.pdf, accessed on June 10, 2021.

SPODAREVA VV, GRYBCHUK-IEREMENKO A, LOSEV A, VOTÝPKA J, LUKEŠ J, YURCHENKO V \& KOSTYGOV AY. 2018. Diversity and evolution of anuran trypanosomes: insights from the study of European species. Parasite Vector 11: 447.

TELFORD SR JR. 2009. Hemoparasites of the Reptilia: Color atlas and text. CRC Press, United States of America.

THOMPSON RC, LYMBERY AJ \& SMITH A. 2010. Parasites, emerging disease and wildlife conservation. Int J Parasitol 40: 1163-1170.

ÚNGARI LP, NETHERLANDS EC, SANTOS ALQ, DE ALCANTARA EP, EMMERICH E, DA SILVA RJ \& O'DWYER LH. 2021. New insights on the diversity of Brazilian anuran blood parasites: With the description of three new species of Hepatozoon (Apicomplexa: Hepatozoidae) from Leptodactylidae anurans. Int J Parasitol Parasites Wild 14: 190-201.

VALENCIA-AGUILAR A, RUANO-FAJARDO G, LAMBERTINI C, LEITE DS, TOLEDO LF \& MOTT T. 2015. Chytrid fungus acts as a generalist pathogen infecting species-rich amphibian families in Brazilian rainforests. Dis Aquat Org 114: 61-67. VICKERMAN KWHR. 1976. The diversity of the kinetoplastid flagellates. Biol Kinetop, p. 1-34.

VIJAY V, PIMM SL, JENKINS CN \& SMITH SJ. 2016. The impacts of oil palm on recent deforestation and biodiversity loss. PLOS ONE 11: e0159668.

VON ZUBEN CJ. 1997. Implicações da agregação espacial de parasitas para a dinâmica populacional na interação hospedeiro-parasita. Rev Saude Publ 31: 523-530.

WOO PT \& BOGART JP. 1984. Trypanosoma spp. (Protozoa: Kinetoplastida) in Hylidae (Anura) from eastern North America, with notes on their distributions and prevalences. Can J Zool 62: 820-824.

ZAR JH. 2010. Biostatistical analysis. $5^{\text {th }}$ ed. Prentice-Hall, New Jersey. 
ZICKUS T. 2002. The first data on the fauna and distribution of blood parasites of amphibians in Lithuania. Acta Zool Lituan 12: 197-202.

\section{How to cite}

PINHO SRC, RODRÍGUEZ-MÁLAGA S, LOZANO-OSORIO R, CORREA FS, SILVA IB \& SANTOS-COSTA MC. 2021. Effects of the habitat on anuran blood parasites in the Eastern Brazilian Amazon. An Acad Bras Cienc 93: e20201703. DOI 10.1590/0001-3765202120201703.

Manuscript received on October 26, 2020;

accepted for publication on September 19, 2021

SÍlVIA R.C. PINHO ${ }^{1,2}$

https://orcid.org/0000-0002-8035-6618

\section{SÉRGIO RODRÍGUEZ-MÁLAGA ${ }^{3}$}

https://orcid.org/0000-0003-3899-4031

\section{RODRIGO LOZANO-OSORIO,}

https://orcid.org/0000-0003-3989-645X

\section{FABRÍCIO S. CORREA ${ }^{2,4}$}

https://orcid.org/0000-0003-4030-2479

IAGO B. SILVA ${ }^{1,2}$

https://orcid.org/0000-0003-2648-3920

MARIA C. SANTOS-COSTA ${ }^{1,2}$

https://orcid.org/0000-0001-5629-5352
${ }^{1}$ Programa de Pós-Graduação em Zoologia, Universidade Federal do Pará e Museu Paraense Emílio Goeldi, Augusto Correia, 1, 66075-110 Belém, PA, Brazil

²Universidade Federal do Pará, Instituto de Ciências Biológicas, Laboratório de Ecologia e Zoologia de Vertebrados, Augusto Correia, 1, 66075-110 Belém, PA, Brazil

${ }^{3}$ Universidade Federal do Pará, Instituto de Ciências Biológicas, Laboratório de Parasitologia, Augusto Correia, 1, 66075-110 Belém, PA, Brazil

${ }^{4}$ Secretaria de Estado de Meio Ambiente e Sustentabilidade, Av. Magalhães Barata, 130, 66040-170 Belém, PA, Brazil

Correspondence to: Sílvia Regina Carneiro de Pinho E-mail: silviahpinho@gmail.com

\section{Author contributions}

SRCP, SRM and MCSC started and designed the study. The fieldwork was carried out by SRCP, IBS, FSC and MCSC. Microscopic analysis, images, map and final data were performed by SRCP, IBS, RLO and SRM. SRCP and FSC interpreted the results and the organization of the manuscript. All authors approved the revisions and the final version.

\section{(cc) BY}

